\title{
Role of $\gamma$-glutamyltranspeptidase in the pathogenesis of Helicobacter suis and Helicobacter pylori infections
}

\author{
Guangzhi Zhang, Richard Ducatelle, Ellen De Bruyne, Myrthe Joosten, Iris Bosschem, Annemieke Smet, \\ Freddy Haesebrouck ${ }^{*+}$ and Bram Flahou ${ }^{*+}$
}

\begin{abstract}
Helicobacter (H.) suis can colonize the stomach of pigs as well as humans, causing chronic gastritis and other gastric pathological changes including gastric ulceration and mucosa-associated lymphoid tissue (MALT) lymphoma. Recently, a virulence factor of $H$. suis, $\gamma$-glutamyl transpeptidase (GGT), has been demonstrated to play an important role in the induction of human gastric epithelial cell death and modulation of lymphocyte proliferation depending on glutamine and glutathione catabolism. In the present study, the relevance of GGT in the pathogenesis of $H$. suis infection was studied in mouse and Mongolian gerbil models. In addition, the relative importance of $\mathrm{H}$. suis GGT was compared with that of the H. pylori GGT. A significant and different contribution of the GGT of $H$. suis and $H$. pylori was seen in terms of bacterial colonization, inflammation and the evoked immune response. In contrast to $H$. pylori $\Delta g g t$ strains, H. suis $\Delta g g t$ strains were capable of colonizing the stomach at levels comparable to WT strains, although they induced significantly less overall gastric inflammation in mice. This was characterized by lower numbers of T and B cells, and a lower level of epithelial cell proliferation. In general, compared to WT strain infection, ggt mutant strains of $\mathrm{H}$. suis triggered lower levels of Th1 and Th17 signature cytokine expression. A pronounced upregulation of B-lymphocyte chemoattractant CXCL13 was observed, both in animals infected with WT and ggt mutant strains of H. suis. Interestingly, H. suis GGT was shown to affect the glutamine metabolism of gastric epithelium through downregulation of the glutamine transporter ASCT2.
\end{abstract}

\section{Introduction}

Helicobacter (H.) pylori is a Gram-negative bacterium that colonizes the stomach of more than half of the world's population. Infection with this bacterium can cause gastritis, peptic ulcer disease, gastric adenocarcinoma and mucosa-associated lymphoid tissue (MALT) lymphoma [1-3]. Besides H. pylori, non-H. pylori helicobacters (NHPH) have also been detected in the stomach of humans and these bacteria cause similar gastric diseases. The risk of developing gastric MALT lymphoma is higher during NHPH infection compared to infection with H. pylori [4-9]. H. suis is the most prevalent gastric $\mathrm{NHPH}$ in humans. Pigs are the natural host of this bacterium, with prevalences reaching $90 \%$ or more [10] and

\footnotetext{
*Correspondence: freddy.haesebrouck@ugent.be; bram.flahou@ugent.be ${ }^{\dagger}$ Equal contributors

Department of Pathology, Bacteriology and Avian Diseases, Faculty of Veterinary Medicine, Ghent University, 9820 Merelbeke, Belgium
}

most likely, pigs and possibly also pork are the main sources of human $H$. suis infection [4,11-13].

H. suis infection seems to persist for life, at least in pigs and rodents used as models for human infections [14]. In pigs, infection causes development of gastritis and a decrease in body weight gain. Moreover, the bacterium seems to play a role in the development of ulceration of the non-glandular pars oesophagea [15]. In mice and Mongolian gerbil models of human gastric disease, experimental $H$. suis infection causes severe gastric pathology $[4,16,17]$, including gastritis, parietal cell necrosis and the development of gastric MALT lymphoma-like lesions, resembling the lesions observed in $H$. suis-infected humans.

Previous studies have shown that this bacterium lacks a homologue for several virulence factors of H. pylori, such as the cytotoxin associated genes pathogenicity island (cagPAI) and the vacuolating cytotoxin (VacA) [18]. We were, 
however, capable of identifying the $\gamma$-glutamyl transpeptidase (GGT) as an important virulence factor of $H$. suis. This enzyme has been described to cause gastric epithelial cell damage [19] and modulation of lymphocyte proliferation [20] through the interaction of the enzyme with two of its substrates, L-glutamine and reduced glutathione, making it the first identified and investigated $H$. suis virulence determinant.

The role of GGT during H. pylori infection in vivo has been investigated in mice. Conflicting conclusions have been drawn regarding the importance of GGT for colonization. Some groups have concluded that $H$. pylori GGT is required for persistent infection in mice [21], while others have made contrary conclusions [22]. In addition, there is accumulating evidence that Helicobacter GGT is a crucial virulence factor involved in immune evasion and immune tolerance [23-25].

Currently, it is unknown if and how H. suis GGT influences the course of $H$. suis infection in vivo. The aim of the present study was to extend our previous in vitro findings with $H$. suis GGT, and to study the role of this virulence factor in the pathogenesis of $H$. suis infection in vivo. At the same time, we aimed at comparing its relative importance with that of the GGT of H. pylori. The current experiments were performed in BALB/c mice and outbred Mongolian gerbils, since these animal models have indeed been shown to be valuable tools to investigate the role of Helicobacter species in gastric pathology. Typically, in Mongolian gerbils, a more rapid and severe development of gastric lesions can be observed compared to mice $[4,26,27]$.

\section{Material and methods}

Animal and bacterial strains

Sixty 4-week-old, female specific-pathogen-free (SPF) BALB/c mice were purchased from Harlan NL (Horst, The Netherlands). Twenty-five 4-week-old, female SPF outbred Mongolian gerbils (Crl:MON) were obtained from Charles River Laboratories (Lille, France).

For $H$. suis infection in mice and Mongolian gerbils, strain HS5cLP was used. This strain has been isolated in 2008 from the stomach of a slaughterhouse pig [28]. For experimental $H$. pylori infection in Mongolian gerbils, strain PMSS1 [29] was used, since this strain has no history of in vivo adaptation in mice, in contrast to the mouse-adapted strain SS1. In BALB/c mice, $H$. pylori strain SS1 [29] was used, since strain PMSS1 has previously been demonstrated not to be able to colonize the stomach of BALB/c mice [29].

\section{Construction of isogenic ggt mutant strains of $H$. suis and H. pylori}

An isogenic $H$. suis ggt mutant strain (HS5cLP $\Delta g g t)$ was prepared as described previously [20]. The isogenic ggt mutant strain of $H$. pylori was obtained using the same strategy as for creation of the H. suis isogenic ggt mutant, except that a kanamycin resistance cassette was used instead of a chloramphenicol resistance cassette [20]. Very briefly, deletion of ggt in H. pylori SS1 and PMSS1 was introduced by allelic exchange using pBluescript II SK (+) phagemid vector (Agilent Technologies, California, USA) in which $\sim 440$ bp of the $5^{\prime}$-end and $\sim 430$ bp of the $3^{\prime}$-end of the target gene and the kanamycin resistance cassette from plasmid pKD4 [30] were ligated through a PCR-mediated strategy with 2 cycles of inverse PCR and fusion PCR [20]. All primers used for PCR-mediated construction of the recombinant plasmids are shown in Table 1 . The resultant plasmid was amplified in XL1-Blue MRF' E. coli (Agilent Technologies) and used as a suicide plasmid in H. pylori SS1 and PMSS1 (a kind gift from Sara Lindén and Anne Muller, respectively). The $H$. pylori SS1 ggt mutant (SS1 $g g t$ ) and $H$. pylori PMSS1 ggt mutant (PMSS1 $g g t$ )

Table 1 Primers used for construction of the $H$. pylori ggt isogenic mutant strains

\begin{tabular}{|c|c|c|}
\hline Primer name & Sequence $\left(5^{\prime}-3^{\prime}\right)$ & Primer use \\
\hline pBlue linear Fwd 1 & GGGGATCCACTAGTTCTAGAGCG & Linearization of plasmid \\
\hline pBlue linear Rev1 & CGGGCTGCAGGAATTCGATATCAAG & Linearization of plasmid \\
\hline HpGGT-flank_fusion1F & CTTGATATCGAATTCCTGCAGCCCGTAACCGGTAAAATCAACACGGACGC & $\begin{array}{l}\text { Amplification H. pylori ggt and partial up- and } \\
\text { downstream flanking genes }\end{array}$ \\
\hline HpGGT-flank_fusion1R & CGCTCTAGAACTAGTGGATCCCCGCGCTCTTATAAAAAGAAGCCGC & $\begin{array}{l}\text { Amplification H. pylori ggt and partial up- and } \\
\text { downstream flanking genes }\end{array}$ \\
\hline pBluelinear_Hpggtflank1F & CCAAGGAAAGAATTTTAATCCTATTTAG & Linearization of the recombinant plasmid \\
\hline pBluelinear_Hpggtflank1R & CTGTTTCCTTTCAATCAACAATAATC & Linearization of the recombinant plasmid \\
\hline Hpkana_fusion_1F & ATTATTGTTGATTGAAAGGAAAACAGATGATTGAACAAGATGGATTGC & Amplification kanamycin resistance gene \\
\hline Hpkana_fusion_1R & CTAAATAGGATTAAAATTCTTTCCTTGGTCAGAAGAACTCGTCAAGAAG & Amplification kanamycin resistance gene \\
\hline T7 prom3 & TAATACGACTCACTATAGGG & Sequencing \\
\hline M13R & CAGGAAACAGCTATGAC & Sequencing \\
\hline
\end{tabular}


were obtained by electrotransformation [31] or natural transformation [32] as described previously. Finally, bacteria were selected on columbia agar plates (Oxoid, Basingstoke, UK) with Vitox supplement (Oxoid), 5\% (v/v) defibrinated sheep blood (E\&O Laboratories Ltd, Bonnybridge, UK), and kanamycin $(25 \mu \mathrm{g} / \mathrm{mL})$. The plates were incubated for 5-9 days. The isogenic ggt mutants were verified by a GGT activity assay [19], PCR and nucleotide sequencing.

\section{Culture conditions of bacterial strains}

Wild-type (WT) H. suis strain HS5cLP was grown for $48 \mathrm{~h}$ as described previously [29]. HS5cLP $\Delta g g t$ bacteria were grown under the same conditions as strain HS5cLP, except that the cultivation plates were supplemented with chloramphenicol $(30 \mu \mathrm{g} / \mathrm{mL})$ as described previously [20].

WT H. pylori strains SS1 and PMSS1 were grown on Columbia agar plates containing $5 \%(\mathrm{v} / \mathrm{v})$ defibrinated sheep blood for $48-72 \mathrm{~h}$ at $37{ }^{\circ} \mathrm{C}$ under microaerobic conditions as described previously [29]. Subsequently, colonies were picked up and cultured in Brucella broth supplemented with Vitox (Oxoid) and 5\% fetal calf serum (HyClone) on a rotational shaker under microaerobic conditions (16 h, 125 rpm). SS1 $\operatorname{lggt}$ and PMSS1 $1 g g t$ strains were cultured under the same conditions as the corresponding WT strains on plates supplemented with kanamycin $(25 \mu \mathrm{g} / \mathrm{mL})$.

\section{Experimental design}

Upon arrival, sixty BALB/C mice and twenty-five Mongolian gerbils were divided into 5 groups, and the animals were allowed to acclimate to the new environment for 1 week. Animals were inoculated intragastrically 3 times at $48 \mathrm{~h}$ intervals. Animals from group 1 and 2 (both mice and Mongolian gerbils) were inoculated with Brucella broth containing $8 \times 10^{7}$ viable bacteria of strains HS5cLP and HS5cLP $\Delta g g t$, respectively. Animals in group 3 and 4 were inoculated with Brucella broth containing $3 \times 10^{8}$ viable bacteria of strains SS1 and SS1 $\Delta g g t$ (mice) or $1 \times 10^{9}$ viable bacteria of strains PMSS1 and PMSS1 1 ggt (gerbils). Animals in the fifth group were inoculated with Brucella broth and served as uninfected controls. For mice, at 4 weeks, 9 weeks and 6 months post infection (pi), 4 animals from each group were euthanized by cervical dislocation under isoflurane anaesthesia. For Mongolian gerbils, all animals were sacrificed at 9 weeks pi. The stomachs of the animals were resected for further processing as described previously $[27,29]$.

Animal experiments were approved by the Ethical Committee of the Faculty of Veterinary Medicine, Ghent University, Belgium (EC2013/29).

\section{Histopathological examination and immunohistochemistry (IHC)}

Three longitudinal strips of gastric tissue from mice and Mongolian gerbils were cut from the oesophagus to the duodenum along the greater curvature. Tissue was fixed in $4 \%$ phosphate buffered formaldehyde, processed by standard methods and embedded in paraffin for light microscopy. Five serial sections of $5 \mu \mathrm{m}$ were cut. The first section was stained with haematoxylin/eosin (H\&E) to score the degree of gastritis according to the Updated Sydney System with some modifications [33]. After deparaffinization and rehydration for the remaining sections, heat-induced antigen retrieval was performed in citrate buffer $(\mathrm{pH}=6.0)$. In order to block endogenous peroxidase activity and non-specific reactions, all the slides were incubated with $3 \% \mathrm{H}_{2} \mathrm{O}_{2}$ in methanol (5 min) and $30 \%$ goat serum (30 min), respectively. For the differentiation between $\mathrm{T}$ and $\mathrm{B}$ lymphocytes, CD3 and CD20 antigens were stained on sections two and three, using a polyclonal rabbit anti-CD3 antibody (1/100; DakoCytomation, Glostrup, Denmark) and a polyclonal rabbit anti-CD20 antibody (1/25; Thermo Scientific, Fremont, USA), respectively. These sections were further processed with Envision + System-HPR (DAB) (DakoCytomation) for use with rabbit primary antibodies. On the fourth and fifth section, epithelial cell proliferation and the number of parietal cells were determined by IHC staining, using a mouse monoclonal antiKi67 antibody (1/25; Menarini Diagnostics, Zaventem, Belgium) and mouse monoclonal anti-hydrogen potassium ATPase $\beta$-subunit $\left(\mathrm{H}^{+} / \mathrm{K}^{+}\right.$ATPase $)$antibody $(1 / 25$ 000; Abcam Ltd, Cambridge, UK), respectively. Subsequent visualization was done with Envision + SystemHPR (DAB) (DakoCytomation) for use with mouse primary antibodies. Quantification of $\mathrm{T}$ cells, B cells and epithelial cells were performed as described previously [4]. Briefly, the numbers of cells belonging to defined cell populations ( $\mathrm{T}$ cells, B cells, and epithelial cells) were determined by counting the positive cells in five randomly chosen High Power Fields (magnification: $x$ 400 ), both in the antrum and corpus region.

In order to assess the possible development of pseudopyloric metaplasia induced by Helicobacter infection, alcian blue-periodic acid-schiff stain staining (AB/PAS) was performed.

\section{Quantification of colonizing bacteria in the stomach of mice and Mongolian gerbils}

Strips of gastric tissue containing all regions for mice and separate pieces (antrum and corpus) for Mongolian gerbils were stored in $0.5 \mathrm{~mL}$ RNAlater solution (Ambion, Austin, TE, USA) at $-70{ }^{\circ} \mathrm{C}$ until RNA and DNA extraction. Quantitative Real-Time PCR (qRT-PCR) was used to 
determine the number of colonizing bacteria in the gastric tissue as described previously $[29,34]$.

\section{RNA extraction and reverse transcription}

qRT-PCR was used to determine gene expression in the gastric tissue from mice and Mongolian gerbils. Total RNA was extracted using the RNeasy Mini Kit (Qiagen, Hilden, Germany) according to the manufacturer's instructions. The concentration of RNA was measured using a NanoDrop spectrophotometer (Isogen Life Science, PW De Meern, Utrecht, The Netherlands). The purity of the RNA was evaluated with the Experion automated electrophoresis system using StdSens RNA chips (Bio-Rad, Hercules CA, USA). The RNA concentration from all samples was adjusted to $1 \mu \mathrm{g} / \mu \mathrm{L}$ and cDNA was synthesized immediately after RNA purification using the iScript ${ }^{\mathrm{mm}}$ cDNA Synthesis Kit (Bio-Rad).

\section{Design and validation of primers and determination of gene expression}

The housekeeping genes H2afz, PPIA and HPRT were included as reference genes for mice [29]. For Mongolian gerbils, a set of reference genes was tested based on the fact that they are extensively used in other animal species. Primers were designed based on the conserved regions of ACTB, $\beta$-actin, RPS18, GAPDH, HPRT1, SDHA and UBC complete or partial coding sequences available for humans, pigs, mice and rats.

The mRNA expression levels of various cytokines (IFN- $\gamma$, IL-4, IL-5, IL-17, IL-1 $\beta$, IL-6, IL-10), previously shown to be differentially expressed during $H$. suis infection, as well as other genes (Foxp3, CXCL13, ASCT2, ATP4a, and ATP4b) were quantified using SYBR Green based RT-PCR with iQ $^{\text {m }}$ SYBR Green Supermix. Reactions were performed using a CFX96 RT PCR System in a C1000 Thermal Cycler (Bio-Rad) as described previously [29]. All reactions were performed in $12 \mu \mathrm{L}$ volumes containing $0.05 \mu \mathrm{L}$ of each primer $(1.25 \mathrm{pmol} / \mu \mathrm{L})$, $6 \mu \mathrm{L} \mathrm{iQ}^{\text {tm }}$ SYBR Green Supermix, $3.9 \mu \mathrm{L}$ HPLC water and $2 \mu \mathrm{L}$ cDNA. The experimental program consisted of $95{ }^{\circ} \mathrm{C}$ for $15 \mathrm{~min}$, followed by 40 cycles of denaturation at $95{ }^{\circ} \mathrm{C}$ for $20 \mathrm{~s}$, annealing at $60^{\circ} \mathrm{C}$ for $30 \mathrm{~s}$, and extension at $72{ }^{\circ} \mathrm{C}$ for $30 \mathrm{~s}$. The threshold cycle values $(\mathrm{Ct})$ were normalized to the geometric means of the reference genes and the normalized mRNA levels of all target genes were calculated using the method of $2^{-\Delta \Delta \mathrm{Ct}}$ [35].

Due to the unavailability of gene information for Forkhead/winged helix transcription factor (Foxp3) and the chemokine CXC ligand 13 (CXCL13) from Mongolian gerbils, primers were designed based on the conserved regions of Foxp3 and CXCL13 complete or partial coding sequences available for humans, pigs, mice and rats with the same strategy as described above. The mRNA expression levels of Foxp3 and CXCL13 were determined using the same method as described above. Sequence information of all the primers for mice and for Mongolian gerbils is shown in Tables 2 and 3.

\section{Statistical analysis}

Differences in colonization capacity were analyzed using a non-parametric Mann-Whitney $U$ test. Differences in lymphocytic infiltration, cytokine expression and IHC analysis were assessed with one-way ANOVA followed by a Bonferroni post hoc test. Statistical analyses were performed using SPSS Statistics 20 software (IBM). Pairwise comparisons were done for each individual timepoint and on pooled data using time as stratification factor. $P$ values less than 0.05 were considered statistically significant. All data are expressed as mean \pm SD. All the figures were created using GraphPad Prism5 software (GraphPad Software Inc., San Diego, CA, USA).

Table 2 List of genes and primers used for qRT-PCR in Mongolian gerbils

\begin{tabular}{|c|c|c|c|}
\hline Gene & Primer & Sequence $\left(5^{\prime}-3^{\prime}\right)$ & References \\
\hline \multirow[t]{2}{*}{ Foxp3 } & sense & GCCCCTMGTCATGGTGGCA & This study \\
\hline & antisense & CCGGGCCTTGAGGGAGAAGA & \\
\hline \multirow[t]{2}{*}{ CXCL13 } & sense & GAATGGCTGCCCCAAAACTGAA & This study \\
\hline & antisense & TCACTGGAGCTTGGGGAGTTGAA & \\
\hline \multirow[t]{2}{*}{ GAPDH } & sense & AACGGGAAGCTCACTGGCATG & This study \\
\hline & antisense & CTGCTTCACCACCTTCTTGATGTCA & \\
\hline \multirow[t]{2}{*}{ HPRT1 } & sense & GCCCCAAAATGGTTAAGGTTGCA & This study \\
\hline & antisense & TCAAGGGCATATCCAACAACAAAC & \\
\hline \multirow[t]{2}{*}{ RPS18 } & sense & CGAGTACTCAACACCAACATCGATGG & This study \\
\hline & antisense & ATGTCTGCTITCCTCAACACCACATG & \\
\hline \multirow[t]{2}{*}{$I L-1 \beta$} & sense & GGCAGGTGGTATCGCTCATC & {$[64]$} \\
\hline & antisense & CACCTTGGATITGACПCTA & \\
\hline \multirow[t]{2}{*}{ IFN- $\gamma$} & sense & CCATGAACGCTACACACTGCATC & {$[65]$} \\
\hline & antisense & GAAGTAGAAAGAGACAATCTGG & \\
\hline \multirow[t]{2}{*}{ IL-5 } & sense & AGAGAAGTGTGGCGAGGAGAGACG & {$[27]$} \\
\hline & antisense & ACAGGGCAATCCCTTCATCGG & \\
\hline \multirow[t]{2}{*}{ IL-6 } & sense & GAGGTGAAGGATCCAGGTCA & {$[66]$} \\
\hline & antisense & GAGGAATGTCCTCAGCTTGG & \\
\hline \multirow[t]{2}{*}{$\| L-10$} & sense & GGTTGCCAAGCCTTATCAGA & {$[27]$} \\
\hline & antisense & GCTGCATTCTGAGGGTCTTC & \\
\hline \multirow[t]{2}{*}{$1 L-17$} & sense & AGCTCCAGAGGCCCTCGGAC & {$[64]$} \\
\hline & antisense & AGGACCAGGATCTCTTGCTG & \\
\hline \multirow[t]{2}{*}{ ATP4b } & sense & GGGGGTAACCTTGAGACCTGATG & {$[27]$} \\
\hline & antisense & AAGAAGTACCTITCGACGTGCAG & \\
\hline \multirow[t]{2}{*}{$\beta$-actin } & sense & TCCTCCCTGGAGAAGAGCTA & {$[66]$} \\
\hline & antisense & CCAGACAGCACTGTGTTGGC & \\
\hline
\end{tabular}




\begin{tabular}{|c|c|c|c|}
\hline Gene & Primer & Sequence $\left(5^{\prime}-3^{\prime}\right)$ & References \\
\hline \multirow[t]{2}{*}{$I L-1 \beta$} & sense & GGGCCTCAA AGGAAAGAATC & [29] \\
\hline & antisense & TACCAGTTGGGGAACTCTGC & \\
\hline \multirow[t]{2}{*}{ IFN- $\gamma$} & sense & GCGTCATTGAATCACACCTG & {$[29]$} \\
\hline & antisense & TGAGCTCATTGAATGCTTGG & \\
\hline \multirow[t]{2}{*}{ IL-4 } & sense & ACTCTTTCGGGCTTTTCGAT & {$[29]$} \\
\hline & antisense & AAAAATTCATAAGTTAAAGCATGGTG & \\
\hline \multirow[t]{2}{*}{ IL-10 } & sense & ATCGATTTCTCCCCTGTGAA & {$[29]$} \\
\hline & antisense & CACACTGCAGGTGTITAGCTT & \\
\hline \multirow[t]{2}{*}{$1 L-17$} & sense & TITAACTCCCTTGGCGCAAAA & {$[29]$} \\
\hline & antisense & CTTTCCCTCCGCATTGACAC & \\
\hline \multirow[t]{2}{*}{ Foxp3 } & sense & GCCCCTMGTCATGGTGGCA & This study \\
\hline & antisense & CCGGGCCTTGAGGGAGAAGA & \\
\hline \multirow[t]{2}{*}{ CXCL13 } & sense & CTCTCCAGGCCACGGTATT & {$[67]$} \\
\hline & antisense & TAACCATTTGGCACGAGGAT & \\
\hline \multirow[t]{2}{*}{ ATP4a } & sense & TGCTGCTATCTGCCTCATTG & {$[68]$} \\
\hline & antisense & GTGCTCTTGAACTCCTGGTAG & \\
\hline \multirow[t]{2}{*}{ ATP4b } & sense & AACAGAATTGTCAAGTTCCTC & {$[68]$} \\
\hline & antisense & AGACTGAAGGTGCCATTG & \\
\hline \multirow[t]{2}{*}{ HPRT } & sense & CAGGCCAGACTTTGTTGGAT & {$[29]$} \\
\hline & antisense & TTGCGCTCATCTTAGGCTTT & \\
\hline \multirow[t]{2}{*}{ PPIA } & sense & AGCATACAGGTCCTGGCATC & {$[29]$} \\
\hline & antisense & ТTCACCTTCCCAAAGACCAC & \\
\hline \multirow[t]{2}{*}{ Hzafz } & sense & CGTATCACCCCTCGTCACTT & {$[29]$} \\
\hline & antisense & TCAGCGATTTGTGGATGTGT & \\
\hline
\end{tabular}

\section{Results}

\section{Colonization density}

All control animals were negative for Helicobacter. Results of infected animals showed that WT $H$. suis can persistently colonize the mouse stomach with colonization levels as high as $5.42 \times 10^{4}\left( \pm 1.46 \times 10^{4}\right)$ bacteria/mg gastric tissue even at 6 months pi (Figure 1C). H. pylori strain SS1 was shown to colonize the mouse stomach at a much lower bacterial density, being $1.68 \times 10^{3}\left( \pm 1.73 \times 10^{3}\right)$ bacteria/mg tissue at 6 months pi (Figure $1 \mathrm{C}, p<0.05$ ).

Interestingly, $H$. suis strain HS5cLP $\Delta g g t$ was able to colonize the corpus of the stomach of the mice to a similar extent as the WT strain, and this was observed for all timepoints (Figures $1 \mathrm{~A}-1 \mathrm{C}$ ). In contrast, $H$. pylori strain SS1 $\operatorname{ggt}$ was shown to have an impaired colonization capacity in mice at all three timepoints (Figures $1 \mathrm{~A}-1 \mathrm{C}, p<0.05)$. Similar colonization data were demonstrated in the antrum of Helicobacter infectedmice at all three timepoints (data not shown).

Both the HS5cLP and HS5cLP $\Delta g g t$ strain successfully colonized the antrum and corpus of the stomach of Mongolian gerbils, although colonization rates were much lower in the corpus compared to the antrum. No statistically significant differences were observed between both strains (Figure 1D, $p>0.05$ ). H. pylori strain PMSS1 $1 g g t$ was able to colonize the antrum and corpus of the stomach at similar levels compared to PMSS1 (Figure 1D, $p>0.05$ ), although 2 out 5 Mongolian gerbils were negative for the presence of PMSS1 $1 g g t$ in the corpus of the stomach (data not shown).

\section{Infection-induced inflammation}

All control mice and gerbils showed normal gastric histomorphology at all timepoints. The correlation between inflammation scores and bacterial colonization is displayed in Figure 1.

Compared to mice with WT strain infection, infection with $H$. suis strain HS5cLP $\Delta g g t$ generally induced significantly less overall inflammation both in the antrum $(p<0.01)$ and corpus $(p<0.01)$, whereas only in the corpus region $(p<0.01)$, infection with $H$. pylori strain SS1 1 ggt induced less inflammation, compared to that seen in WT strain infected mice. At 6 months pi, the corpus region in 2 out of 4 mice with HS5cLP infection contained large lymphoid aggregates or lymphoid follicles accompanied by destruction of the normal mucosal architecture (Figure 2A), which was not observed in animals from other groups.

For Mongolian gerbils, infection with HS5cLP or PMSS1 induced severe antrum-dominant gastritis with formation of lymphocytic aggregates in the lamina propria and/or sub-mucosa of the stomach (Figures 1D, 2E, and 2G). No significant differences were observed between the WT and mutant strain of $H$. suis with respect to the inflammatory response induced in gerbils (Figures 1D, 2E and 2F), although all animals infected with strain HS5cLP showed inflammation in the corpus region, whereas this was only the case for some animals infected with HS5cLP $\Delta g g t$ (data not shown). In one gerbil infected with $H$. suis strain HS5cLP, a pronounced inflammatory response was observed, in which more than $65 \%$ of the area in the lamina propria and submucosa of the antrum was densely infiltrated with inflammatory cells, fused lymphoid aggregates and lymphoid follicles (Additional file 1).

Inflammation induced by $H$. pylori strain PMSS1 $\Delta g g t$ in the antrum of gerbils was less severe compared to that seen in WT infected animals $(p<0.05)$ (Figures 1D, $2 \mathrm{G}$ and $2 \mathrm{H})$.

\section{Inflammatory cell infiltration}

In general, an increase of $\mathrm{T}$ cell numbers was observed in the corpus (Figure 3A, $p<0.05$ ) of mice infected with $H$. suis strain HS5cLP and $H$. pylori strain SS1 at all three timepoints. Compared to the mice infected with WT $H$. suis, HS5cLP $\Delta g g t$ induced a lower T cell response in the 

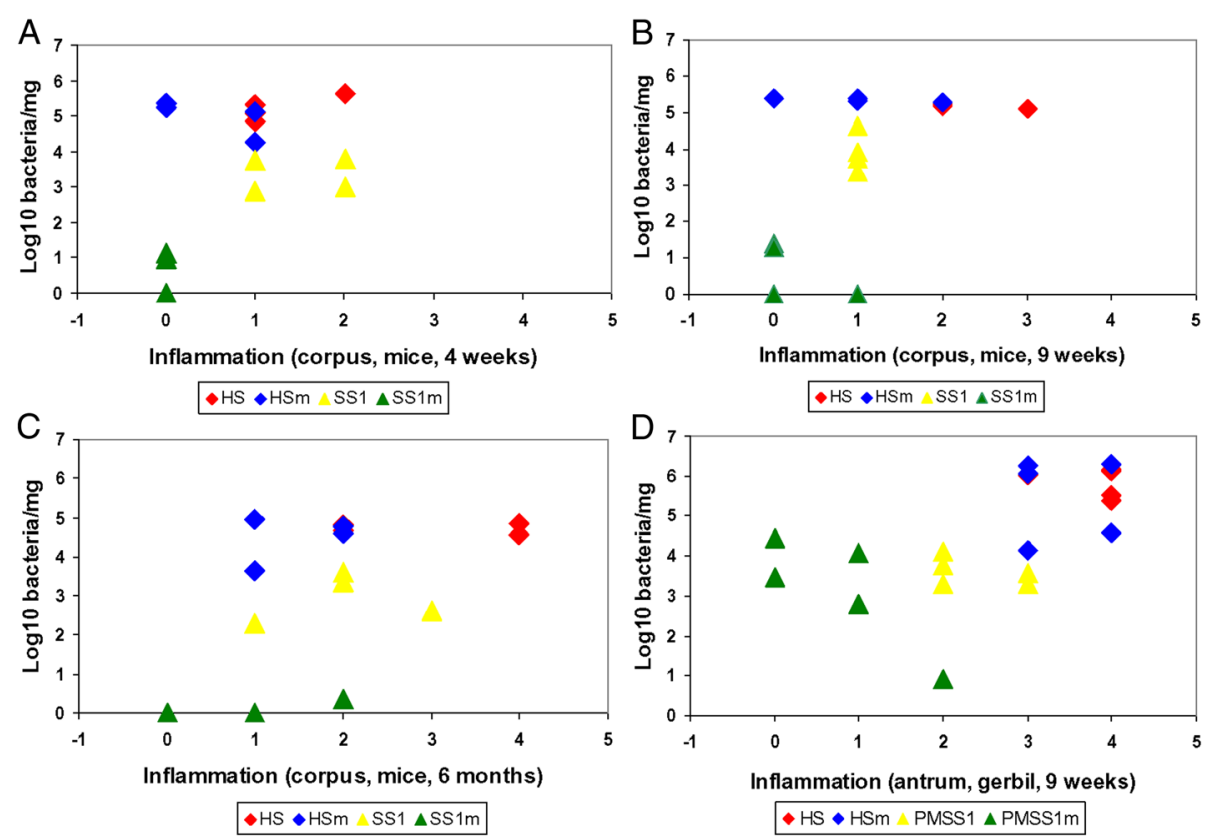

Figure 1 Correlation between bacterial colonization capacity and inflammation score in the stomach of mice and Mongolian gerbils. The colonization capacity is shown as log 10 values of $\mathrm{H}$. suis or $\mathrm{H}$. pylori per mg tissue, determined with qRT-PCR in the corpus of mice (A-C) and antrum of Mongolian gerbils (D). 0 , no infiltration with mononuclear and/or polymorphonuclear cells; 1 , very mild diffuse infiltration with mononuclear and/or polymorphonuclear cells or the presence of one small (20-50 cells) aggregate of inflammatory cells; 2 , mild diffuse infiltration with mononuclear and/or polymorphonuclear cells or the presence of one small (50-200 cells) aggregate of inflammatory cells; 3, moderate diffuse infiltration with mononuclear and/or polymorphonuclear cells and/or the presence of $2-4$ inflammatory aggregates; 4 , marked diffuse infiltration with mononuclear and/or polymorphonuclear cells and/or the presence of at least five inflammatory aggregates. HS vs. HSm: Colonization: $p>0.05$; Inflammation: $p<0.05$. SS1 vs. SS1 m: Colonization: $p<0.05$; Inflammation: $p<0.05$. PMSS1 vs. PMSS1m: Colonization: $p>0.05$; Inflammation: $p<0.05$. HS: animals infected with WT H. suis srain HS5CLP; HSm: animals infected with H. suis strain HS5cLPAggt; SS1: animals infected with WT H. pylori SS1; SS1m: animals infected with $H$. pylori SS1 $\Delta$ ggt; PMSS1: animals infected with WT H. pylori PMSS1; PMSS1 m: animals infected with $H$. pylori PMSS1 $\Delta$ ggt.

corpus at 6 months pi $(p<0.01)$. H. pylori strain SS1 $\Delta g g t$ induced a reduced $\mathrm{T}$ cell response in the corpus region $(p<0.01)$ compared to WT infected animals, at both 9 weeks and 6 months pi (Figure 3A). Similar results were observed in the antrum of mice (data not shown).

An increase of B cell numbers was observed in the corpus mucosa of mice infected with strain HS5cLP $(p<0.01)$ and SS1 $(p<0.01)$ at 6 months pi (Figure 3B). Compared to the WT H. suis infected mice, HS5cLP $\Delta g g t$ induced a lower $\mathrm{B}$ cell response in the corpus region of mice at 6 months pi $(p<0.05)$ and a similar reduction was observed in SS1 $\Delta g g t$ infected mice $(p<0.01)$ (Figure 3B).

For Mongolian gerbils, an exact quantification of $\mathrm{T}$ and B lymphocytes was not performed since the inflammation was characterized by a marked diffuse infiltration with large numbers of lymphocytes and large inflammatory aggregates. Histopathological analysis showed a pronounced increase of T cell numbers as well as lymphocytic aggregates and follicles in the lamina propria and tunica submucosa in all groups (Figures 4A-4D), although this was most pronounced in the antrum of both WT and mutant $H$. suis infected animals (Figures $4 \mathrm{~A}-4 \mathrm{~B}$ ). $\mathrm{T}$ cell infiltration levels induced by PMSS1 $\Delta g g t$ infection were lower compared to that seen in WT H. pylori infected animals (Figures 4C and 4D).

WT and mutant strains of $H$. suis induced similar levels of B cell infiltration, mainly in the centre of lymphocytic aggregates/follicles in the antrum (Figures $4 \mathrm{E}$ and $4 \mathrm{~F}$ ). WT $H$. pylori induced mild B cell infiltration in the antrum of gerbils, whereas animals with PMSS1 $\Delta g g t$ infection did not show an obvious B cell infiltration (Figures 4G and $4 \mathrm{H})$. A marked proliferation of $\mathrm{B}$ cells in germinal centers was observed in gerbils infected with $H$. suis strains HS5cLP (Additional file 2A) and HS5cLP $\Delta g g t$ (Additional file 2B) but not in $H$. pylori infected animals.

\section{Epithelial cell-related changes}

For mice, IHC staining did not reveal a clear decrease of the number of parietal cells in the stomach, except for mice infected with $H$. suis strain HS5cLP for 6 months $(p<0.05)$. For Mongolian gerbils, a clear loss of parietal cells was only observed in the transition zone between corpus and antrum in H. suis strain HS5cLP (Additional file $3 \mathrm{~B}$ ) and HS5cLP $\Delta g g t$ (Additional file 3C) infected 

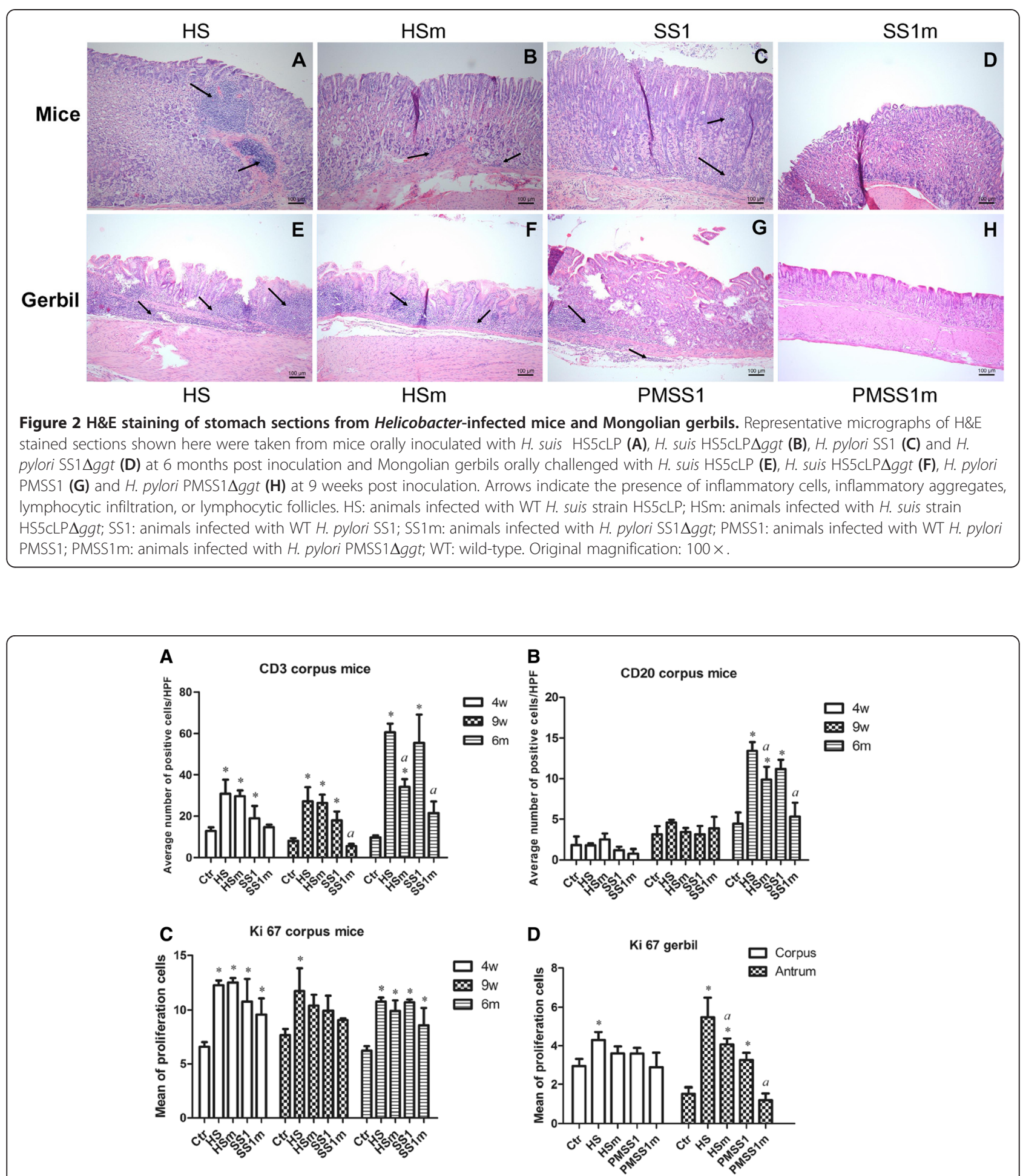

Figure 3 Quantitative analysis of defined cell populations with immunohistochemistry. (A-B) Shown are the average ( \pm SD) numbers of cells/ High Power Field, including T cells (CD3-positive) and B cells (CD20-positive) in the corpus of the stomach of mice. (C-D) Shown are the average $( \pm$ SD) numbers of epithelial cells in five randomly chosen microscopic fields at the level of the gastric pits in the stomach from mice and Mongolian gerbils. An* represents a statistically significant difference $(p<0.05)$ between infected and control groups. An $a$ represents a statistically significant difference $(p<0.05)$ between WT Helicobacter infected groups and isogenic ggt mutant infected groups. Ctr: animals from control group; HS: animals infected with WT H. suis strain HS5CLP; HSm: animals infected with H. suis strain HS5cLP $\Delta g g t$; SS1: animals infected with WT H. pylori SS1; SS1m: animals infected with H. pylori SS1 $\Delta$ ggt; PMSS1: animals infected with WT H. pylori PMSS1; PMSS1m: animals infected with H. pylori PMSS1 $\Delta g$ g; WT: wild-type; 3w: 3 weeks post infection; 9w: 9 weeks post infection; 6 m: 6 months post infection. 


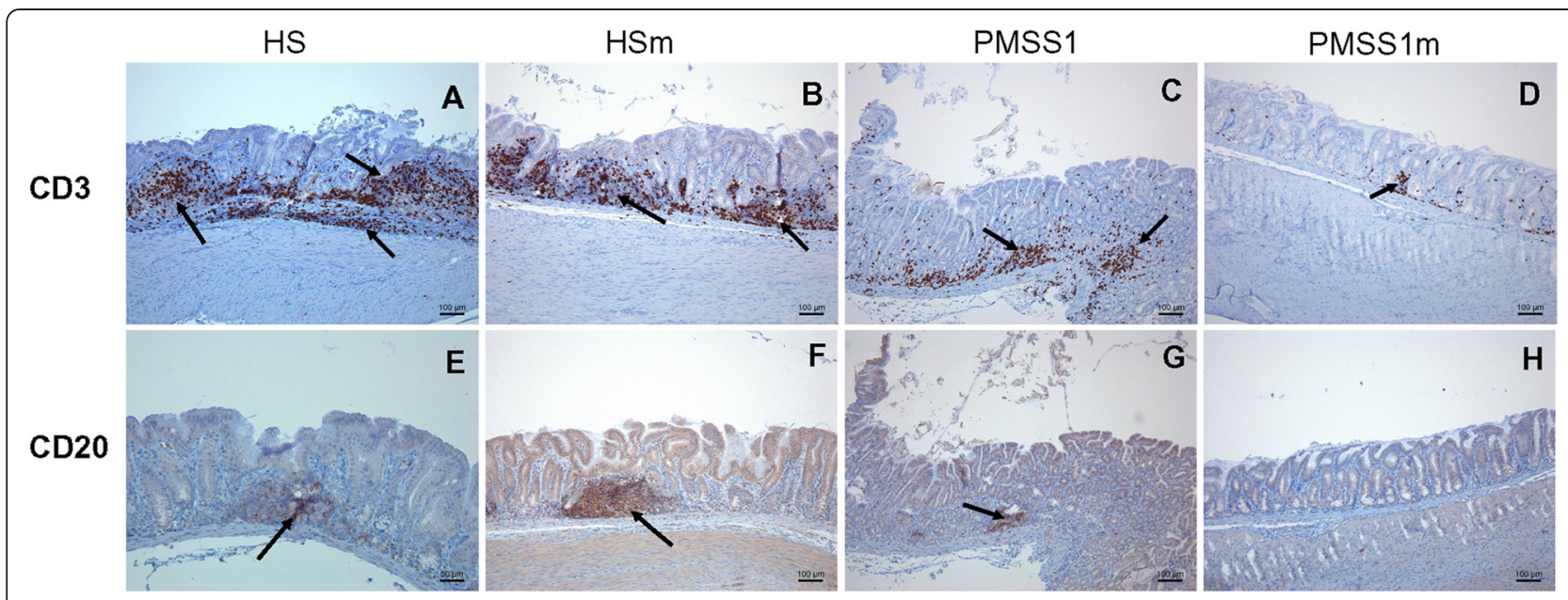

Figure 4 Gastric inflammation of Helicobacter-infected Mongolian gerbils. CD3 staining of the antrum of the stomach from Mongolian gerbils inoculated with H. suis HS5CLP (A), H. suis HS5CLPAggt (B), H. pylori PMSS1 (C) and H. pylori PMSS1 $\Delta$ ggt (D) at 9 weeks post inoculation, showing T-lymphocytes (brown). CD20 staining of the antrum of a gerbil infected with WT H. suis HS5CLP (E), H. suis HS5CLP $\Delta$ ggt (F), WT H. pylori PMSS1 (G) and H. pylori PMSS1 $\Delta g g t$ (H) at 9 weeks post inoculation, showing B lymphocytes (brown) in germinal centers of lymphoid follicles (arrows) or lymphoid aggregates (arrows). HS: animals infected with WT H. suis strain HS5CLP; HSm: animals infected with H. suis strain HS5CLPAggt; PMSS1: animals infected with WT H. pylori PMSS1; PMSS1 m: animals infected with H. pylori PMSS1 $\Delta g g t$; WT: wild-type. Original magnification: $100 \times$.

animals, but not in H. pylori PMSS1 or PMSS1 1 ggt infected animals (Additional files 3D and 3E).

Data on gastric epithelial cell proliferation in the corpus region are summarized in Figures $3 \mathrm{C}$ and 3D. Compared to control mice, an increased epithelial cell proliferation was seen in the corpus (Figure $3 C, p<0.05$ ) of HS5cLP infected mice at all timepoints, and a similar increase was observed for SS1 infected mice (Figure 3C, $p<0.05)$. In general, mice infected with $H$. suis and $H$. pylori strains mutated for the GGT revealed somewhat lower epithelial cell proliferation rates compared to WT strain infected mice (Figure 3C), which was, however, not statistically significant. Compared to WT strain infected Mongolian gerbils, both HS5cLP $\Delta g g t(p<0.05)$ and PMSS1 $\operatorname{ggt}(p<0.01)$ infected animals revealed a significantly lower level of epithelial cell proliferation in the antrum (Figure 3D).

$\mathrm{AB} / \mathrm{PAS}$ staining showed that $H$. suis infection triggered the development of pseudopyloric metaplasia to a varying degree in the corpus region of mice at 6 months pi (Additional files 4B and 4C). Compared to WT H. suis infection, infection with HS5cLP $\Delta g g t$ in general led to less obvious regions affected by pseudopyloric metaplasia. Infection with WT H. pylori also induced pseudopyloric metaplasia to a varying degree in the corpus region of mice at 6 months pi (Additional file 4D), whereas strain SS1 $\Delta g g t$ did not (Additional file 4E).

\section{Cytokine secretion in response to bacterial infection}

Data on gene expression levels are presented in Figures 5 and 6.
Primers for housekeeping genes of Mongolian gerbils were chosen based on the specificity and amplification efficiency of the primers, and stable expression levels of the genes. $\beta$-actin, RPS18, GAPDH and HPRT1 were included as the final reference genes for qRT-PCR performed in gerbils.

\section{IFN- $\gamma$ and IL-1 $\beta$}

In general, only $H$. pylori strain SS1 infection induced a significant up-regulation of the Th1 signature cytokine IFN- $\gamma$ in mice (Figure 5A, $p<0.05$ ). WT and mutant strains of H. suis $(p<0.01)$ and H. pylori $(p<0.01)$ induced a pronounced upregulation of IFN $-\gamma$ expression in the antrum of infected Mongolian gerbils (Figure 5C), and no significant differences were observed between WT infected-and mutant infected animals.

No significant differences of IL-1 $\beta$ expression were observed between groups (data not shown). In Mongolian gerbils, similarly increased expression levels of IL- $1 \beta$ were seen in animals infected with WT and mutant strains of $H$. suis (data not shown).

\section{IL-4, IL-5, IL-6, IL-10}

In general, compared to control mice, the expression of anti-inflammatory IL-10 was upregulated in $H$. suis strain HS5cLP and HS5cLP $\Delta g g t$ infected mice (Figure 5A, $p<0.01)$. A very similar expression pattern was observed for Foxp3 (Figure 5B, $p<0.01$ ), an important cell marker of $\mathrm{CD}^{+} / \mathrm{CD} 25^{+}$regulatory $\mathrm{T}$ cells (Tregs), which are one of the most important cell types secreting IL-10 [36].

In Mongolian gerbils, a clear increase of IL-10 expression, compared to control animals, was demonstrated 


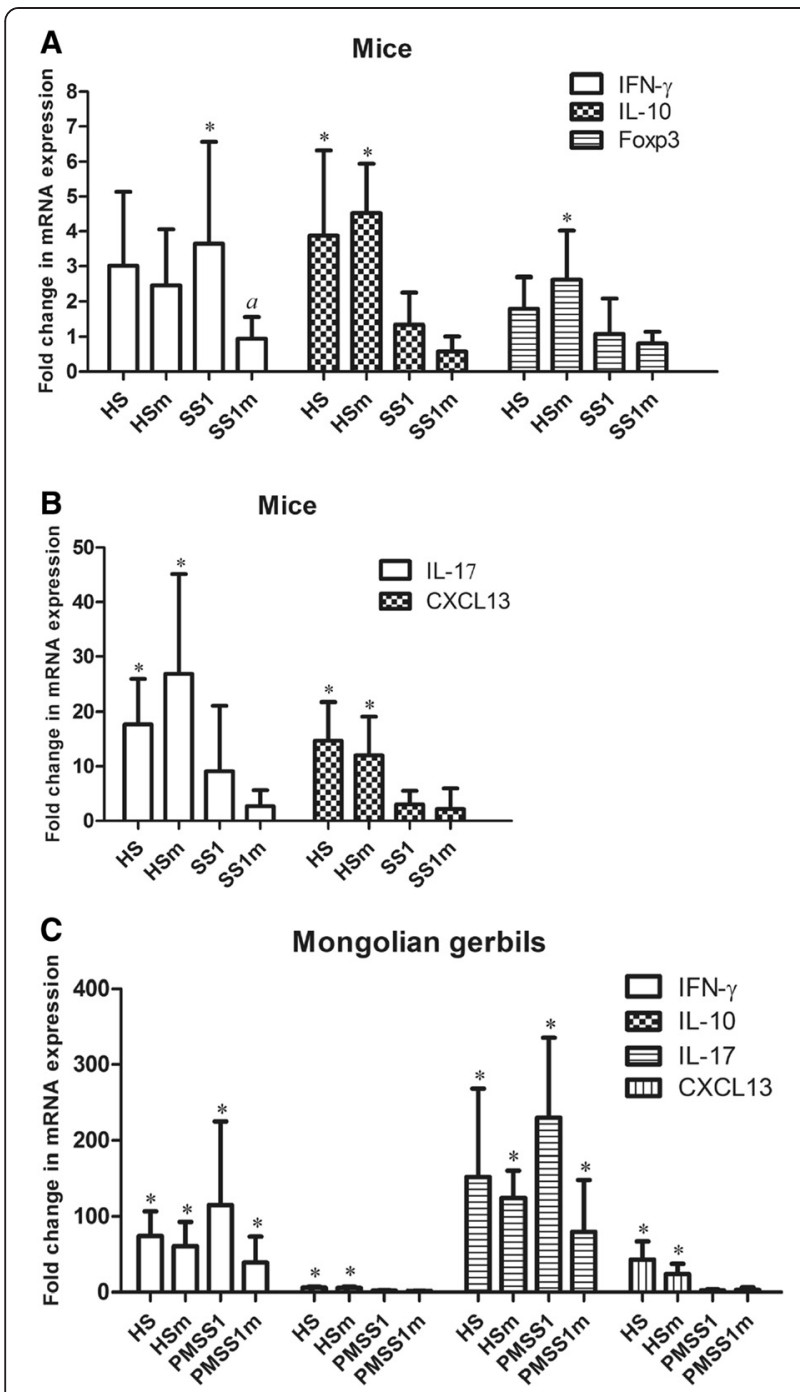

Figure 5 Cytokine expression patterns in the stomach of mice and Mongolian gerbils infected with $H$. suis and $H$. pylori. Shown are the mean fold changes of mRNA expression in infected mice (A-B) and gerbils (C) for IFN-Y, IL-10, Foxp3, IL-17, CXCL13. The mean fold changes in the relevant uninfected control groups is equal to 1 . An * indicates a statistically significant difference $(p<0.05)$ between infected and control groups. An a indicates a statistically significant difference $(p<0.05)$ between WT Helicobacter infected groups and isogenic ggt mutant infected groups. HS: animals infected with WT H. suis strain HS5CLP; HSm: animals infected with $H$. suis strain HS5CLPAggt; SS1: animals infected with WT H. pylori SS1; SS1m: animals infected with $H$. pylori SS1 $\Delta g g t ;$ PMSS1: animals infected with $H$. pylori PMSS1; PMSS1m: animals infected with $H$. pylori PMSS1 1 ggt; WT: wild-type.

both in the antrum of gerbils infected with strain HS5cLP $(p<0.01)$ and strain HS5cLP $\Delta g g t$ (Figure 5C, $p<0.01$ ). Compared to control animals, no significant changes of IL-10 and Foxp3 expression levels were observed in animals infected with $H$. pylori (Figures 5A and 5C).

Compared to control animals, an upregulation of IL-6 expression was only demonstrated in gerbils with
HS5cLP and HS5cLP $\Delta g g t$ infection, but no difference was observed between both groups (data not shown). No significant differences in expression between control animals and infected animals could be demonstrated for IL-4 and IL-5 (data not shown).

\section{IL-17}

IL-17 is a Th17 response signature cytokine. A notable increase of IL-17 expression was generally observed in mice infected with WT $H$. suis (Figure $5 \mathrm{~B}, p<0.05$ ). Similar expression levels were observed for HS5cLP $\Delta g g t$ infected mice (Figure 5B, $p<0.05$ ).

In Mongolian gerbils, both WT and mutant $H$. suis and $H$. pylori infection generally induced increased levels of IL-17 expression (Figure $5 \mathrm{C}, p<0.01$ ). These levels were lower in HS5cLP $\Delta g g t$ and PMSS1 $1 g g t$ infected gerbils compared to WT infected animals, which was, however, not statistically significant (Figure 5C, $p>0.05$ ), most likely due to the limited number of animals in each group.

\section{CXCL13}

CXCL13 plays an important role during the B-cell homing to follicles in lymph nodes and spleen and formation of gastric lymphoid follicles [37], and it is involved in the pathogenesis of Helicobacter infection [14,37]. In general, infection with both HS5cLP and HS5cLP $\Delta g g t$ induced a marked upregulation of CXCL13 in mice (Figure 5B, $p<0.01$ ). Moreover, an even higher increase of CXCL13 expression levels was observed in the antrum of gerbils infected with $H$. suis strains HS5cLP and HS5cLP $\Delta g g t$ compared to control gerbils (Figure 5C, $p<0.01)$. No statistically significant differences of CXCL13 expression levels were observed between HS5cLP and HS5cLP $\Delta g g t$ infected animals (Figures 5B and 5C).

\section{Changes of epithelial cell-related factors in the stomach}

The $\mathrm{H}^{+} / \mathrm{K}^{+}$ATPase is responsible for gastric acid secretion by parietal cells [38]. Compared to uninfected control mice, a clear decrease of Atp $4 a$ (Figure 6A, $p<0.05$ ) and Atp $4 b(p<0.05$, data not shown) mRNA expression levels was detected in the stomach of HS5cLP and SS1 infected mice at 9 weeks pi. In addition, a statistically higher expression of Atp $4 a$ (Figure 6A, $p<0.05$ ) and Atp $4 b \quad(p<0.05$, data not shown) was observed in HS5cLP $\Delta g g t$ infected mice compared to WT infected animals.

ASCT2 is an important glutamine transporter for the growth of epithelial cells and other cell types [39]. Compared to control animals, infection with $H$. suis strain HS5cLP resulted in a downregulation of ASCT2 expression in mice at 9 weeks pi (Figure 6B, $p<0.05$ ), and infection with $H$. suis strain HS5cLP $\Delta g g t$ revealed significantly higher ASCT2 expression levels compared to 


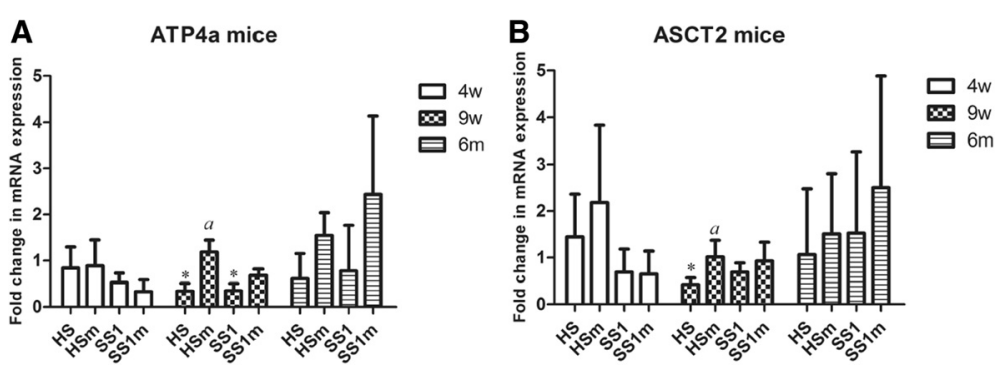

Figure 6 Expression of epithelial cell-associated factors. Shown are the mean fold changes of mRNA expression in infected mice for ATP4a (A) and ASCT2 (B). The mean fold changes in the relevant uninfected control groups is equal to 1. An * indicates a statistically significant difference $(p<0.05)$ between infected and control groups. An a indicates a statistically significant difference $(p<0.05)$ between WT Helicobacter infected groups and isogenic ggt mutant infected groups. HS: animals infected with WT H. suis strain HS5cLP; HSm: animals infected with H. suis strain HS5CLPAggt; SS1: animals infected with WT H. pylori SS1; SS1m: animals infected with H. pylori SS1 $\Delta g g$ t; PMSS1: animals infected with H. pylori PMSS1; PMSS1 m: animals infected with H. pylori PMSS1 $\Delta g g t$; WT: wild-type; 3w: 3 weeks post infection; 9w: 9 weeks post infection; 6 m: 6 months post infection.

WT H. suis infection (Figure $6 \mathrm{~B}, p<0.05$ ). Similar results were observed in $H$. pylori infected mice, without being statistically significant (Figure 6, $p>0.05$ ).

\section{Discussion}

Although, in the present study, H. suis strain HS5cLP $\Delta g g t$ was shown to be able to colonize the stomach of mice at similar levels compared to WT H. suis, it induced significantly less overall inflammation in both corpus and antrum. This suggests that the $H$. suis GGT is involved in the induction and regulation of the inflammatory response, without being an essential factor for colonization. However, in Mongolian gerbils, H. suis strain HS5cLP $\Delta g g t$ was shown to induce only a slightly milder inflammatory response compared to the WT H. suis strain. This implies that, besides GGT, $H$. suis harbours other virulence factors or bacterial components, involved in the generation and modulation of the host immune response. In a previous study performed in vitro, lysate from HS5cLP $\Delta g g t$ indeed was shown to still have an effect on the proliferation and function of $\mathrm{T}$ lymphocytes, further suggesting the presence of hitherto unidentified factors in $H$. suis that can modulate the host immune and inflammatory response [20]. These factors remain to be investigated in the future.

Interestingly and in contrast to what we observed for $H$. suis lacking GGT, $H$. pylori strains SS1 $\Delta g g t$ and PMSS1 1 ggt failed to persistently colonize the stomach of mice and gerbils, highlighting the different relative contributions of $H$. pylori GGT and H. suis GGT to the colonization ability in these rodent models. In any case, data from the current study as well as previous studies on the H. pylori GGT show that the H. pylori GGT confers a benefit to $H$. pylori in terms of its colonization capacity, at least in mice and gerbils, whereas the H. suis GGT mainly affects the inflammatory response evoked during $H$. suis infection without having a notable impact on the levels of bacterial colonization. Since H. suis lacks several other virulence determinants of $H$. pylori, such as VacA, the role of $H$. suis GGT in inducing or shaping the host immune response appears to be relatively important.

Our study reveals that $H$. suis infection induces a Th17 response in mice, without a significant upregulation of Th1 cytokines such as IFN- $\gamma$. This confirms the results of a previous study in which both Th1- and Th2prone mouse strains were used [29]. However, the use of Mongolian gerbils in the present study demonstrated that $H$. suis infection can induce a marked upregulation of IFN- $\gamma$ expression in this animal model, which is accompanied by a more pronounced gastritis compared to that seen in mice. For H. pylori, it has been demonstrated that infection induces the expression of IFN- $\gamma$ in both mice and gerbils, which plays a pivotal role in promoting mucosal inflammation. This in turn contributes to more pronounced gastric mucosal damage [40]. Thus, the higher levels of IFN- $\gamma$ expression in gerbils infected with $H$. suis most likely contribute to the more pronounced inflammation observed in this animal model compared to that in mice.

IL-10 is considered an important anti-inflammatory cytokine, which is mainly produced by regulatory $\mathrm{T}$ cells and dendritic cells [41], and this cytokine has been described to be upregulated in WT $H$. suis infected mice [29]. In the present study, we observed a similar expression pattern for IL-10 and Foxp3 in mice. This may indicate that the secretion of IL-10 mainly occurs through Tregs in the stomach, which needs to be confirmed in future studies. It may be postulated that the higher levels of IL-10 expression in HS5cLP $\Delta g g t$ infected mice are partially responsible for the attenuated inflammatory response, when compared to WT-infected animals. Previously published data from in vitro experiments have shown that $H$. pylori GGT suppresses IL-10 secretion by activated human $\mathrm{CD}_{4}^{+} \mathrm{T}$ cells [42], which is supported 
by our findings. The enzyme has, however, also been described to reprogram DC towards a tolerogenic phenotype, which was shown to depend upon increased secretion of IL-10 [43].

A pronounced upregulation of CXCL13 expression levels was observed in $H$. suis-infected animals, which was shown to be independent of the presence of $H$. suis GGT. Interestingly, a similar upregulation was completely absent in H. pylori-infected animals. Possibly, however, a longer experimental period (e.g. 12-18 months) may induce upregulation of CXCL13 expression in the stomach of these animals as well. CXCL13, also named B-cell-attracting chemokine-1 or B-lymphocyte chemoattractant, is a CXC subtype member of the chemokine superfamily [44], and it may play a pivotal role in various immune and inflammatory conditions as well as $H$. pylori-associated gastritis in humans $[45,46]$. It has been shown that the expression of CXCL13 is significantly upregulated in gastric MALT lymphoma in both humans [47] and mice [48]. The pronounced upregulation of CXCL13 as well as the presence of a clear proliferation of B-cells in germinal centers in the present study seem to be in line with the higher risk to develop gastric MALT lymphoma in humans infected with NHPH compared to H. pylori infected patients [5,49-51]. A recent report showed that the formation of gastric lymphoid follicles after challenge with gastric mucosal homogenate from a monkey harbouring $H$. suis was efficiently suppressed by the administration of anti-CXCL13 antibodies [14]. Taken together, this shows that CXCL13 might be one of the key cytokines involved in the development of gastric MALT lymphoma associated with $H$. suis infection.

In previous experiments we have shown that $H$. suis GGT inhibits the proliferation of lymphocytes in vitro through the interaction with glutamine [20]. This seems contradictory to the results of the present in vivo study showing that animals infected with $H$. suis strain HS5cLP $\Delta g g t$ exhibited a lower lymphocytic infiltration rate in the gastric mucosa. Besides lymphocytes, however, H. suis and its GGT also target gastric mucosal epithelial cells [19]. The uncontrolled loss of epithelial cells by cell death, e.g. necrosis, also triggers the influx of inflammatory cells, in turn promoting the further development of inflammation. In line with some of our previous studies [4], H. suis infection indeed affected the function of gastric acid secreting parietal cells, as shown by the decreased expression levels of Atp $4 a$ and Atp $4 b$, and the mutant work demonstrated that $H$. suis GGT indeed plays a role. In addition, the present study indicates that the epithelial (hyper)proliferation observed in WT $H$. suis infected mice is more pronounced than in HS5cLP $\Delta g g t$ infected mice. This suggests that $H$. suis lacking GGT causes less damage to the epithelium compared to WT bacteria. Probably, this also has an implication on the subsequent development of inflammation in the presence of a more or less damaged epithelium. However, it remains to be determined whether the impact of the $H$. suis GGT on the health of gastric epithelial cells is stronger compared to its direct effects on lymphocytes residing in the deeper tissue layers, including the inhibitory effect on their proliferation.

As mentioned above, infection with $H$. suis strain HS5cLP in mice induced a clear downregulation of Atp $4 a$ and Atp $4 b$ expression levels in the stomach at 9 weeks and 6 months pi, and such an effect was not observed in the HS5cLP $\Delta g g t$ infected animals, showing that $H$. suis GGT contributes to alterations in gastric acid secretion by parietal cells. Previous reports have shown that $H$. suis is often observed near or inside the canaliculi of parietal cells in the stomach of mice, and colonization of $H$. suis is also closely linked with necrosis of parietal cells in mice and Mongolian gerbils [4]. Besides the direct effect of $H$. suis GGT on the acid secretion by parietal cells, altered expression levels of IL$1 \beta$ may also affect the acid production through multiple pathways [52,53], including a decreased histamine release from enterochromaffin-like cells [54]. The impaired gastric acid secretion and subsequent development of mucous metaplasia observed in the present study, may lead to the development of gastric atrophy, hypochlorhydria and gastric cancer $[55,56]$.

For the first time, we were able to show an effect of $H$. suis GGT on the glutamine metabolism of gastric epithelial cells. This amino acid, targeted by the enzymatic activity of $H$. suis GGT [20], is a major fuel for rapidly dividing cells, including enterocytes, macrophages and lymphocytes $[57,58]$. It is supportive in improving digestion, absorption, and retention of nutrients through affecting tissue anabolism, stress, and immunity, and it also plays an important role in animal nutrition and health. WT $H$. suis infection was shown to cause a significant downregulation of ASCT2 mRNA in mice, while HS5cLP $\Delta g g t$ did not show this effect. This suggests that glutamine depletion catalysed by GGT activity at the level of the gastric mucosa resulted in the downregulation of glutamine transporter ASCT2. ASCT2 is a $\mathrm{Na}^{+}$-dependent, broad-scope neutral amino acid transporter [59,60], which is essential for glutamine uptake by fast growing epithelial cells and tumor cells $[39,61,62]$, and ASCT2 expression levels depend on glutamine availability [63].

In summary, our data show that $H$. suis GGT is not an essential factor for colonization in mice and gerbils, whereas it is involved in the induction of an inflammatory response. This differs to what has been described for the $H$. pylori GGT. In addition, we demonstrated that $H$. suis infection causes a considerable increase of IFN- $\gamma$ expression levels in Mongolian gerbils, which differs from the situation in mice, where $H$. suis infection is 
not accompanied by increased expression of this Th1 signature cytokine. This Th1 response was shown to be attenuated in the absence of $H$. suis GGT. CXCL13 expression levels were shown to be upregulated during $H$. suis infection, in contrast to what we observed for $H$. pylori infection, and this was shown not to depend on the presence of $H$. suis GGT. WT H. suis infection was shown to suppress expression levels of Atp $4 a$ and Atp $4 b$, involved in gastric acid secretion, and to suppress expression levels of the glutamine transporter ASCT2. These effects on the gastric epithelium were clearly related to the presence of $H$. suis GGT.

\section{Additional files}

\section{Additional file 1: H\&E staining of the stomach section from a} Helicobacter suis infected Mongolian gerbil. The vast majority of the antrum of the stomach from this WT H. suis-infected animal was densely infiltrated with inflammatory cells, fused lymphoid aggregates and lymphoid follicles. Original magnification: $25 x$.

Additional file 2: Proliferation of $B$ cells in germinal centers. Representative micrographs of a Ki67 staining of the stomach from a WT $H$. suis infected (A) and H. suis $\Delta$ ggt infected gerbil (B) are shown. Proliferating germinal centers were observed in animals from both groups, but mainly in WT H. suis infected animals. WT: wild-type. Original magnification: $50 \times$ and $200 \times$.

Additional file 3: Immunohistochemical staining of the hydrogen potassium ATPase of parietal cells in the stomach mucosa of Mongolian gerbils. Moderate numbers of parietal cells (brown) are present at the transition zone between the corpus and antrum of the stomach of control Mongolian gerbils (A). A clear loss of parietal cells is observed in the transition zone between the corpus and antrum of the stomach from Mongolian gerbils infected with WT H. suis strain HS5cLP (B) or H. suis strain HS5CLPAggt (C) at 9 weeks post inoculation. No clear change of parietal cell numbers is seen in the transition zone between the corpus and antrum of the stomach from Mongolian gerbils infected with WT H. pylori PMSS1 (D) or H. pylori PMSS1 $19 g t$ (E) at 9 weeks post inoculation. WT: wild-type. Original magnification: $100 \times$

Additional file 4: Determination of mucous metaplasia in the stomach from Helicobacter-infected mice. An AB/PAS staining was applied to determine the presence of pseudopyloric metaplasia (arrows) in the stomachs of control mice (A), WT H. suis infected mice (B), $H$. suis $\Delta g g$ t infected mice $(C), W T H$. pylori infected mice (D), and $H$. pylorisggt infected mice (E) at 6 months post infection. WT: wild-type; AB/PAS: alcial blue-periodic acid-Schiff stain. Original magnification: $100 \times$

\section{Competing interests}

The authors declare that they have no competing interests.

\section{Authors' contributions}

GZZ and BF coordinated the study, designed the study, carried out the experiments, analysed the data and drafted the manuscript. FH coordinated the study, designed the study and drafted the manuscript. EDB, MJ, IB and AS contributed to the experiments, and RD participated in the design of this study and drafting of the manuscript. All authors read and approved the final manuscript.

\section{Authors' information}

Freddy Haesebrouck and Bram Flahou share senior authorship.

\section{Acknowledgements}

This work was supported by grants from China Scholarship Council (CSC) (Grant No. 2010676001) and from the Research Fund of Ghent University, Ghent, Belgium (Grant No. GOA01G00408 and 01SC2411). The authors are grateful to Sofie De Bruyckere and Nathalie Van Rysselberghe for their excellent technical support with qRT-PCR, and we thank Christian Puttevils, Delphine Ameye and Sarah Loomans for their excellent technical help with animal tissue staining, Shaoji Li for the help with animal experiments, and Anja Roevens for the assistance with the experiment.

Received: 18 November 2014 Accepted: 12 February 2015 Published online: 13 March 2015

\section{References}

1. Parsonnet J, Friedman GD, Vandersteen DP, Chang Y, Vogelman JH, Orentreich N, Sibley RK (1991) Helicobacter pylori infection and the risk of gastric carcinoma. N Engl J Med 325:1127-1131

2. Huang JQ, Sridhar S, Chen Y, Hunt RH (1998) Meta-analysis of the relationship between Helicobacter pylori seropositivity and gastric cancer. Gastroenterology 114:1169-1179

3. Ernst PB, Gold BD (2000) The disease spectrum of Helicobacter pylori: the immunopathogenesis of gastroduodenal ulcer and gastric cancer. Annu Rev Microbiol 54:615-640

4. Flahou B, Haesebrouck F, Pasmans F, D'Herde K, Driessen A, Van Deun K, Smet A, Duchateau L, Chiers K, Ducatelle R (2010) Helicobacter suis causes severe gastric pathology in mouse and mongolian gerbil models of human gastric disease. PLoS One 5:e14083

5. Haesebrouck F, Pasmans F, Flahou B, Chiers K, Baele M, Meyns T, Decostere A, Ducatelle R (2009) Gastric helicobacters in domestic animals and nonhuman primates and their significance for human health. Clin Microbiol Rev 22:202-223

6. Joosten M, Flahou B, Meyns T, Smet A, Arts J, De Cooman L, Pasmans F, Ducatelle R, Haesebrouck F (2013) Case report: Helicobacter suis infection in a pig veterinarian. Helicobacter 18:392-396

7. Trebesius K, Adler K, Vieth M, Stolte M, Haas R (2001) Specific detection and prevalence of Helicobacter heilmannii-like organisms in the human gastric mucosa by fluorescent in situ hybridization and partial 165 ribosomal DNA sequencing. J Clin Microbiol 39:1510-1516

8. O'Rourke JL, Dixon MF, Jack A, Enno A, Lee A (2004) Gastric B-cell mucosaassociated lymphoid tissue (MALT) lymphoma in an animal model of 'Helicobacter heilmannii' infection. J Pathol 203:896-903

9. Lee A, Eckstein RP, Fevre DI, Dick E, Kellow JE (1989) Non Campylobacter pylori spiral organisms in the gastric antrum. Aust N Z J Med 19:156-158

10. Hellemans A, Chiers K, De Bock M, Decostere A, Haesebrouck F, Ducatelle R, Maes D (2007) Prevalence of 'Candidatus Helicobacter suis' in pigs of different ages. Vet Rec 161:189-192

11. De Cooman L, Houf K, Smet A, Flahou B, Ducatelle R, De Bruyne E, Pasmans F. Haesebrouck F (2014) Presence of Helicobacter suis on pork carcasses. Int J Food Microbiol 187:73-76

12. De Cooman L, Flahou B, Houf K, Smet A, Ducatelle R, Pasmans F, Haesebrouck F (2013) Survival of Helicobacter suis bacteria in retail pig meat. Int J Food Microbiol 166:164-167

13. Van den Bulck K, Decostere A, Baele M, Driessen A, Debongnie JC, Burette A, Stolte M, Ducatelle R, Haesebrouck F (2005) Identification of non-Helicobacter pylori spiral organisms in gastric samples from humans, dogs, and cats. J Clin Microbiol 43:2256-2260

14. Yamamoto K, Nishiumi S, Yang L, Klimatcheva E, Pandina T, Takahashi S, Matsui H, Nakamura M, Zauderer M, Yoshida M, Azuma T (2014) AntiCXCL13 antibody can inhibit the formation of gastric lymphoid follicles induced by Helicobacter infection. Mucosal Immunol 7:1244-1254

15. De Bruyne E, Flahou B, Chiers K, Meyns T, Kumar S, Vermoote M, Pasmans F, Millet S, Dewulf J, Haesebrouck F, Ducatelle R (2012) An experimental Helicobacter suis infection causes gastritis and reduced daily weight gain in pigs. Vet Microbiol 160:449-454

16. O'Rourke JL, Lee A (2003) Animal models of Helicobacter pylori infection and disease. Microbes Infect 5:741-748

17. Rogers AB, Fox JG (2004) Inflammation and cancer. I. Rodent models of infectious gastrointestinal and liver cancer. Am J Physiol Gastrointest Liver Physiol 286:G361-G366

18. Vermoote M, Vandekerckhove $T$, Flahou B, Pasmans F, Smet A, De Groote D, Van Criekinge W, Ducatelle R, Haesebrouck F (2011) Genome sequence of Helicobacter suis supports its role in gastric pathology. Vet Res 42:51

19. Flahou B, Haesebrouck F, Chiers K, Van Deun K, De Smet L, Devreese B, Vandenberghe I, Favoreel H, Smet A, Pasmans F, D'Herde K, Ducatelle R (2011) Gastric epithelial cell death caused by Helicobacter suis and 
Helicobacter pylori gamma-glutamyl transpeptidase is mainly glutathione degradation-dependent. Cell Microbiol 13:1933-1955

20. Zhang G, Ducatelle R, Pasmans F, D'Herde K, Huang L, Smet A, Haesebrouck F, Flahou B (2013) Effects of Helicobacter suis gamma-glutamyl transpeptidase on lymphocytes: modulation by glutamine and glutathione supplementation and outer membrane vesicles as a putative delivery route of the enzyme. PLoS One 8:e77966

21. Chevalier C, Thiberge JM, Ferrero RL, Labigne A (1999) Essential role of Helicobacter pylori gamma-glutamyltranspeptidase for the colonization of the gastric mucosa of mice. Mol Microbiol 31:1359-1372

22. McGovern KJ, Blanchard TG, Gutierrez JA, Czinn SJ, Krakowka S, Youngman P (2001) Gamma-Glutamyltransferase is a Helicobacter pylori virulence factor but is not essential for colonization. Infect Immun 69:4168-4173

23. Oertli M, Noben M, Engler DB, Semper RP, Reuter S, Maxeiner J, Gerhard M, Taube C, Muller A (2013) Helicobacter pylori gamma-glutamyl transpeptidase and vacuolating cytotoxin promote gastric persistence and immune tolerance. Proc Natl Acad Sci U S A 110:3047-3052

24. Salama NR, Hartung ML, Muller A (2013) Life in the human stomach: persistence strategies of the bacterial pathogen Helicobacter pylori. Nat Rev Microbiol 11:385-399

25. Schmees C, Prinz C, Treptau T, Rad R, Hengst L, Voland P, Bauer S, Brenner L, Schmid RM, Gerhard M (2007) Inhibition of T-cell proliferation by Helicobacter pylori gamma-glutamyl transpeptidase. Gastroenterology 132:1820-1833

26. Wiedemann T, Loell E, Mueller S, Stoeckelhuber M, Stolte M, Haas R, Rieder G (2009) Helicobacter pylori cag-Pathogenicity island-dependent early immunological response triggers later precancerous gastric changes in Mongolian gerbils. PLoS One 4:e4754

27. Joosten M, Blaecher C, Flahou B, Ducatelle R, Haesebrouck F, Smet A (2013) Diversity in bacterium-host interactions within the species Helicobacter heilmannii sensu stricto. Vet Res 44:65

28. Baele M, Decostere A, Vandamme P, Ceelen L, Hellemans A, Mast J, Chiers K, Ducatelle R, Haesebrouck F (2008) Isolation and characterization of Helicobacter suis sp. nov. from pig stomachs. Int J Syst Evol Microbiol 58:1350-1358

29. Flahou B, Deun KV, Pasmans F, Smet A, Volf J, Rychlik I, Ducatelle R, Haesebrouck F (2012) The local immune response of mice after Helicobacter suis infection: strain differences and distinction with Helicobacter pylori. Vet Res 43:75

30. Van Parys A, Boyen F, Verbrugghe E, Leyman B, Bram F, Haesebrouck F, Pasmans F (2012) Salmonella Typhimurium induces SPI-1 and SPI-2 regulated and strain dependent downregulation of MHC II expression on porcine alveolar macrophages. Vet Res 43:52

31. Ferrero RL, Cussac V, Courcoux P, Labigne A (1992) Construction of isogenic urease-negative mutants of Helicobacter pylori by allelic exchange. J Bacteriol 174:4212-4217

32. Wang Y, Roos KP, Taylor DE (1993) Transformation of Helicobacter pylori by chromosomal metronidazole resistance and by a plasmid with a selectable chloramphenicol resistance marker. J Gen Microbiol 139:2485-2493

33. Stolte M, Meining A (2001) The updated Sydney system: classification and grading of gastritis as the basis of diagnosis and treatment. Can J Gastroenterol 15:591-598

34. Blaecher C, Smet A, Flahou B, Pasmans F, Ducatelle R, Taylor D, Weller C, Bjarnason I, Charlett A, Lawson AJ, Dobbs RJ, Dobbs SM, Haesebrouck F (2013) Significantly higher frequency of Helicobacter suis in patients with idiopathic parkinsonism than in control patients. Aliment Pharmacol Ther 38:1347-1353

35. Livak KJ, Schmittgen TD (2001) Analysis of relative gene expression data using real-time quantitative PCR and the 2(-Delta Delta $C(T)$ ) method. Methods 25:402-408

36. Josefowicz SZ, Lu LF, Rudensky AY (2012) Regulatory T cells: mechanisms of differentiation and function. Annu Rev Immunol 30:531-564

37. Ansel KM, Ngo VN, Hyman PL, Luther SA, Forster R, Sedgwick JD, Browning JL, Lipp M, Cyster JG (2000) A chemokine-driven positive feedback loop organizes lymphoid follicles. Nature 406:309-314

38. Chow DC, Forte JG (1995) Functional significance of the beta-subunit for heterodimeric P-type ATPases. J Exp Biol 198:1-17

39. McGivan JD, Bungard Cl (2007) The transport of glutamine into mammalian cells. Front Biosci 12:874-882

40. Smythies LE, Waites KB, Lindsey JR, Harris PR, Ghiara P, Smith PD (2000) Helicobacter pylori-induced mucosal inflammation is Th1 mediated and exacerbated in IL-4, but not IFN-gamma, gene-deficient mice. J Immunol 165:1022-1029

41. Eaton KA, Mefford M, Thevenot T (2001) The role of T cell subsets and cytokines in the pathogenesis of Helicobacter pylori gastritis in mice. J Immunol 166:7456-7461

42. Beigier-Bompadre M, Moos V, Belogolova E, Allers K, Schneider T, Churin Y, Ignatius R, Meyer TF, Aebischer T (2011) Modulation of the CD4 ${ }^{+}$T-cell response by Helicobacter pylori depends on known virulence factors and bacterial cholesterol and cholesterol alpha-glucoside content. J Infect Dis 204:1339-1348

43. Engler DB, Reuter S, van Wijck Y, Urban S, Kyburz A, Maxeiner J, Martin H, Yogev N, Waisman A, Gerhard M, Cover TL, Taube C, Muller A (2014) Effective treatment of allergic airway inflammation with Helicobacter pylori immunomodulators requires BATF3-dependent dendritic cells and IL-10. Proc Natl Acad Sci U S A 111:11810-11815

44. Gunn MD, Ngo VN, Ansel KM, Ekland EH, Cyster JG, Williams LT (1998) A B-cell-homing chemokine made in lymphoid follicles activates Burkitt's lymphoma receptor-1. Nature 391:799-803

45. Galamb O, Gyorffy B, Sipos F, Dinya E, Krenacs T, Berczi L, Szoke D, Spisak S, Solymosi N, Nemeth AM, Juhasz M, Molnar B, Tulassay Z (2008) Helicobacter pylori and antrum erosion-specific gene expression patterns: the discriminative role of CXCL13 and VCAM1 transcripts. Helicobacter 13:112-126

46. Nakashima Y, Isomoto H, Matsushima K, Yoshida A, Nakayama T, Nakayama M, Hisatsune J, Ichikawa T, Takeshima F, Hayashi T, Nakao K, Hirayama T, Kohno S (2011) Enhanced expression of CXCL13 in human Helicobacter pylori-associated gastritis. Dig Dis Sci 56:2887-2894

47. Mazzucchelli L, Blaser A, Kappeler A, Scharli P, Laissue JA, Baggiolini M, Uguccioni M (1999) BCA-1 is highly expressed in Helicobacter pylori-induced mucosa-associated lymphoid tissue and gastric lymphoma. J Clin Invest 104: R49-R54

48. Nobutani K, Yoshida M, Nishiumi S, Nishitani Y, Takagawa T, Tanaka H, Yamamoto K, Mimura T, Bensuleiman Y, Ota H, Takahashi S, Matsui H, Nakamura M, Azuma T (2010) Helicobacter heilmannii can induce gastric lymphoid follicles in mice via a Peyer's patch-independent pathway. FEMS Immunol Med Microbiol 60:156-164

49. Stolte M, Kroher G, Meining A, Morgner A, Bayerdorffer E, Bethke B (1997) A comparison of Helicobacter pylori and H. heilmannii gastritis. A matched control study involving 404 patients. Scand I Gastroenterol 32:28-33

50. Morgner A, Lehn N, Andersen LP, Thiede C, Bennedsen M, Trebesius K, Neubauer B, Neubauer A, Stolte M, Bayerdorffer E (2000) Helicobacter heilmannii-associated primary gastric low-grade MALT lymphoma: complete remission after curing the infection. Gastroenterology 118:821-828

51. Joo M, Kwak JE, Chang SH, Kim H, Chi JG, Kim KA, Yang JH, Lee JS, Moon YS, Kim KM (2007) Helicobacter heilmannii-associated gastritis: clinicopathologic findings and comparison with Helicobacter pylori-associated gastritis. J Korean Med Sci 22:63-69

52. Beales IL, Calam J (1998) Interleukin 1 beta and tumour necrosis factor alpha Inhibit acid secretion in cultured rabbit parietal cells by multiple pathways. Gut 42:227-234

53. Wallace JL, Cucala M, Mugridge K, Parente L (1991) Secretagogue-specific effects of interleukin-1 on gastric-acid secretion. Am J Physiol 261:G559G564

54. Prinz C, Neumayer N, Mahr S, Classen M, Schepp W (1997) Functional impairment of rat enterochromaffin-like cells by interleukin 1 beta. Gastroenterology 112:364-375

55. Kapadia CR (2003) Gastric atrophy, metaplasia, and dysplasia: a clinical perspective. J Clin Gastroenterol 36:S29-S36

56. Correa P (1992) Human gastric carcinogenesis: a multistep and multifactorial process-first american cancer society award lecture on cancer epidemiology and prevention. Cancer Res 52:6735-6740

57. Rhoads JM, Argenzio RA, Chen W, Rippe RA, Westwick JK, Cox AD, Berschneider HM, Brenner DA (1997) L-glutamine stimulates intestinal cell proliferation and activates mitogen-activated protein kinases. Am J Physiol 272:G943-G953

58. Wu G (2009) Amino acids: metabolism, functions, and nutrition. Amino Acids 37:1-17

59. Utsunomiya-Tate N, Endou H, Kanai Y (1996) Cloning and functional characterization of a system ASC-like $\mathrm{Na}+-$-dependent neutral amino acid transporter. J Biol Chem 271:14883-14890

60. Kekuda R, Prasad PD, Fei YJ, Torres-Zamorano V, Sinha S, Yang-Feng TL, Leibach FH, Ganapathy V (1996) Cloning of the sodium-dependent, 
broad-scope, neutral amino acid transporter Bo from a human placental choriocarcinoma cell line. J Biol Chem 271:18657-18661

61. Wang Q, Beaumont KA, Otte NJ, Font J, Bailey CG, van Geldermalsen M, Sharp DM, Tiffen JC, Ryan RM, Jormakka M, Haass NK, Rasko JE, Holst J (2014) Targeting glutamine transport to suppress melanoma cell growth. International journal of cancer. Int J Cancer 135:1060-1071

62. Bode BP, Fuchs BC, Hurley BP, Conroy JL, Suetterlin JE, Tanabe KK, Rhoads DB, Abcouwer SF, Souba WW (2002) Molecular and functional analysis of glutamine uptake in human hepatoma and liver-derived cells. Am J Physiol Gastrointest Liver Physiol 283:G1062-G1073

63. Bungard Cl, McGivan JD (2004) Glutamine availability up-regulates expression of the amino acid transporter protein ASCT2 in HepG2 cells and stimulates the ASCT2 promoter. Biochem J 382:27-32

64. Sugimoto M, Ohno T, Graham DY, Yamaoka Y (2009) Gastric mucosal interleukin-17 and -18 mRNA expression in Helicobacter pylori-induced Mongolian gerbils. Cancer Sci 100:2152-2159

65. Crabtree JE, Court M, Aboshkiwa MA, Jeremy AH, Dixon MF, Robinson PA (2004) Gastric mucosal cytokine and epithelial cell responses to Helicobacter pylori infection in Mongolian gerbils. J Pathol 202:197-207

66. Sugimoto M, Ohno T, Graham DY, Yamaoka Y (2011) Helicobacter pylori outer membrane proteins on gastric mucosal interleukin 6 and 11 expression in Mongolian gerbils. J Gastroenterol Hepatol 26:1677-1684

67. Lee HS, Park JH, Kang JH, Kawada T, Yu R, Han IS (2009) Chemokine and chemokine receptor gene expression in the mesenteric adipose tissue of KKAy mice. Cytokine 46:160-165

68. Jain RN, Brunkan CS, Chew CS, Samuelson LC (2006) Gene expression profiling of gastrin target genes in parietal cells. Physiol Genomics 24:124-132

\section{Submit your next manuscript to BioMed Central and take full advantage of:}

- Convenient online submission

- Thorough peer review

- No space constraints or color figure charges

- Immediate publication on acceptance

- Inclusion in PubMed, CAS, Scopus and Google Scholar

- Research which is freely available for redistribution 